\title{
Hepatotoxicity Induced by High Dose of Methylprednisolone Therapy in a Patient with Multiple Sclerosis: A Case Report and Brief Review of Literature
}

\author{
Mohamed A. H. Kadle, Natalia V. Mazurchik \\ Center for the Study of the Liver, Peoples Friendship University of Russia, Moscow, Russia \\ Email: kadlesom@gmail.com
}

Received 26 March 2016; accepted 20 May 2016; published 23 May 2016

Copyright $@ 2016$ by authors and Scientific Research Publishing Inc.

This work is licensed under the Creative Commons Attribution International License (CC BY). http://creativecommons.org/licenses/by/4.0/

\section{(c) (i) Open Access}

\begin{abstract}
Toxic hepatitis due to drugs is an important and frequent drug adverse reaction in clinical practice. Here, we report a case of high dose methylprednisolone-induced acute hepatitis in a 51-yearold woman that suffers from multiple sclerosis while steroids are usually safe drugs with regards to liver injury and even they are the treatment choice of autoimmune hepatitis, but the literatures about corticosteroids showed are not entirely safe to liver injury and they have occasionally linked to hepatotoxicity. Although recent reports have demonstrated that prednisolone may cause hepatitis. This case report includes a brief review of the relevant literature on corticosteroids-induced hepatitis that is presented.
\end{abstract}

\section{Keywords}

Toxic Hepatitis, Methylprednisolone, Multiple Sclerosis

\section{Introduction}

The injury of the liver may follow pharmacological agents and chemical agents through as inhalation, ingestion or parenteral administration and it is more commonly in pharmacological agents that used in medical therapy rather than chemical agents [1]. In acute liver failure, the major cause is drug-induced liver injury which is the one of significant causes of liver disease with high morbidity and mortality, and it is important that any patient who has jaundice or altered liver function tests should be questioned carefully about the exposure of any drugs or chemicals used, although there is no specific tests that exists of drug-induced liver injury and the diagnosis is 
to performed by exclusion [2] so the challenge factor of this condition is the diagnosis of the disease. Steroids are usually considered to be safe drugs that do not cause drug induced liver injury, and even they are the treatment choice of autoimmune hepatitis, but the literatures about steroids showed are not entirely safe to liver injury and they have occasionally linked to severe hepatotoxicity, although methylprednisolone-induced hepatotoxicity cases are rare but persist on repeated administration and they lead to the poor outcome [3]. We presented a case of a 51-year-old woman who was given methylprednisolone for multiple sclerosis and developed icteric hepatitis and impairment of liver synthetic function during the treatment.

\section{Case Report}

A 51-year old woman complained since 1993 with symptoms of numbness of extremities, unsteadiness in walking and dizziness but these symptoms regressed spontaneously within few weeks, in 2000 diagnosed autoimmune thyroditis and she recovered means euthyroidism. In 2004 and 2012 were marked episodes of headaches for months, pressing character, right sided localization accompanied by nausea for duration up to one day, after that she was stopped Citramon (acetaminophen/aspirin/caffeine). Since 2012 the episodes of disturbed feeling of noise in the right ear but the frequency is not more than one time per month.

About 2 years ago there was a numbness in the feet, which is spontaneously regressed within few weeks, then symptoms reappeared and spreads to the lower legs, since that time this symptomatology persists and gradually joined the awkwardness and weakness in the legs.

In March 2015 Brain MRI highlighted multifocal loss of brain and demyelinating in nature while MRI of the thoracic spinal cord showed an intramedullary-level body Th1, Th4, Th7, Th10 determined foci of high intensity in T2 mode. Another MRI of the brain revealed white matter lesion hemispheres up to $10 \mathrm{~mm}$ in the barrel of the size up to $2.5 \mathrm{~mm}$ in left cerebellar peduncles up to $2 \mathrm{~mm}$ and Visual evoked potentials (VEP) revealed there are changes in demyelinating type of the 2 sides. There is a positive neurological reflex typical of the underlying disease. On the basis of clinical symptoms, MRI data and the presence of oligoclonal IgG antibodies in CSF and the diagnosis of multiple sclerosis was made.

It was admitted to the Research Center of Neurology with 05.12.15 on 02.06.15, before hospitalization data provided HIV tests (antigen + antibody)-negative, HBsAg, Anti-HCV-and, Wassermann reaction (WR) were negative; X-rays of the chest were showed normal. A blood test for thyroid hormones: TSH $2.69 \mathrm{mkIE} / \mathrm{ml} \mathrm{T4sv.}$ $-0.65 \mathrm{ng} / \mathrm{dL}$, AT to TPO-> $1087 \mathrm{IU} / \mathrm{ml}$. Treatment was performed with initial bolus doses of methylprednisolone (500 mg/in No. 10, $1.2 \mathrm{mg} / \mathrm{kg}$ ) was given in May 2015, without any abnormalities on blood tests, including liver enzymes, but it was marked by severe weakness. Prior to the steroid pulse, ALT, AST and GGT were normal, and control blood tests were also normal after discharged the hospital.

After hospitalization continued weakness, loss of appetite, body weight loss of $15 \mathrm{~kg}$ in a month. Seven weeks after discharged was marked jaundice and the liver function tests were altered: ALT $1032 \mathrm{U} / \mathrm{l}$ (35 U/L), AST $2076 \mathrm{U} / \mathrm{l}$ (35 U/L), total bilirubin, $475 \mathrm{mmol} / \mathrm{L}$ (5 - $21 \mathrm{mmol} / \mathrm{l})$, alkaline phosphatase $178 \mathrm{U} / \mathrm{l}$ (35 - $104 \mathrm{U} / \mathrm{L})$ Cholesterol $3.06 \mathrm{mmol} / \mathrm{l}$ (3.60 - $5.2 \mathrm{mmol} / \mathrm{l})$; after that the Neurology Research Center was referred to our center of the study of liver disease.

When patient came to our center of study of liver disease she was complained general weakness, loss of appetite, her BMI is 15.62, physical examination showed only jaundice and there is no sign of the chronic liver disease were detected including liver and spleen in size on palpation and it was confirmed cytolysis syndrome and cholestasis; while abdominal ultrasound showed a diffuse changes and sings of portal hypertension with extension of $1.5 \mathrm{~cm}$, and her laboratory tests were demonstrated elevated liver enzymes with serum levels of: alanine aminotransferase (ALT) 1047 IU/L (n: 7 - 45 IU/L), aspartate aminotransferase (AST) 1774 IU/L (n: 7 - 40 IU/L), gamma-glutamyl transpeptidase (GGT) $186 \mathrm{IU} / \mathrm{L}$ (n: 7 - $39 \mathrm{IU} / \mathrm{L}$ ), total bilirubin 427 micromol/L, direct bilirubin 310.7 micromol/L ( $<7.9$ micromol/L) indirect bilirubin 116.5 micromol/L and alkaline phosphatase $175 \mathrm{U} / \mathrm{l}(35-104 \mathrm{U} / \mathrm{L}$ ), Thus, the most likely cause of the jaundice and expressed cytolysis presented drug-induced hepatitis. Appointed ursodeoxycholic acid at a dose of $1000 \mathrm{mg} / \mathrm{day}$. Two weeks later the level of liver function tests improved spontaneously with levels of ALT 373 IU/L, AST 483 IU/L, GGT 102 IU/L and total bilirubin 191.7 micromol/L/L (5 - 21 micromol/L), direct bilirubin 278 micromol/L ( $<7.9$ micromol/L) indirect bilirubin $92 \mathrm{micromol} / \mathrm{L}$ ( $<19 \mathrm{micromol} / \mathrm{L}$ ). The results of Transient Elastography is $22.8 \mathrm{KPa}$ of liver stiffness measurements and are useful means of estimating the severity of hepatic fibrosis/cirrhosis, an ultrasound control showed the emergence of a small amount of fluid in the pelvis and other control blood tests was showed normal. 
A systematic search of classical causes of acute hepatitis was performed, and the results showed that the serum HAV IgM antibodies, HBsAg, anti-HCV antibodies (hepatitis C) were all negative. Similarly, the antinuclear antibodies was under the upper limit of significance (1/160), and the anti-mitochondrial, anti-smooth muscle, and anti-LKM 1 (liver-kidney microsome 1) antibodies, gp210, PML, Sp100, M2-3E, SSA/Ro-52, AT with ASGPR were negative. However, other immunological abnormalities were highlighted: anti-gastric parietal cell antibodies were positive (1/640). The levels of ceruloplasmin and AFP were normal and no data for thrombosis (D-dimer). Abdominal ultrasound examination was revealed an intact liver and normal-sized spleen.

Finally laboratory perturbation of the patient was showed normalization of liver function tests after the withdrawal of methylprednisolone and the value of Transient Elastography is $6.8 \mathrm{kPa}$, which corresponds to F0 (No fibrosis), and full recovery of the patient with arranged a follow-up appointments to our center.

Table 1 shows laboratory values prior and posttreatment while the remaining laboratory values are shown in Table 2.

\section{Discussion}

In general hepatotoxic drugs can injure the hepatocyte directly and it can be divided into two main categories (1) direct toxic and (2) idiosyncratic. The direct toxic hepatitis occurs with predictable regularity in patients that exposed to the agents and it is related to the dose dependent, while the idiosyncratic is unpredictable and it seem to be dose-independent; it usually occurs within days to months to start of injury [4] [5]. Sometimes patients may developed liver toxicity after the drugs was stopped even in months [6]. Corticosteroids related hepatotoxicity is thought to be an idiosyncratic reaction to steroids and their metabolites or it could be due to compounds used as preservatives. The mechanisms by which corticosteroids might produce hepatic injury are unclear and only occasionally are related to reactivation of HBV infection or the excipient of the methylprednisolone preparation or its metabolite. However, the low doses of corticosteroids are considered to be safe for the liver, chronic administration of these drugs may be related by steatosis or steatohepatitis [4]. Such that serious of hepatic injury that related to methylprednisolone occur rarely and unpredictable to cause hepatotoxicity, so the confirmation of drug-induced liver injury needs exclusion of other viral and immunological diseases. For the risk of sever liver injury that is caused by methylprednisolone may prevent its progression the time of recognition of this complication and withdrawal of the drug [7] [8], we report a serious idiosyncratic liver injury in a patient with multiple sclerosis that were related to high dose of methylprednisolone treatment. An unintentional re-challenge test in 2015 was confirmed the relationship of methylprednisolone and the onset hepatotoxicity.

In order to get more information about overview of high-dose methylprednisolone induced hepatitis in patients

\begin{tabular}{|c|c|c|c|c|c|c|c|c|}
\hline $\begin{array}{l}\text { Date } \\
2015\end{array}$ & ALT(IU/I) & $\begin{array}{l}\text { AST } \\
\text { (IU/l) }\end{array}$ & $\begin{array}{l}\text { GGT } \\
\text { (IU/I) }\end{array}$ & $\begin{array}{c}\text { ALP } \\
\text { (IU/l) }\end{array}$ & $\begin{array}{c}\text { TOTAL } \\
\text { BILRUBIN } \\
\text { (micromol/L) }\end{array}$ & $\begin{array}{c}\text { DIRECT } \\
\text { BILRUBIN } \\
\text { (micromol/L) }\end{array}$ & $\begin{array}{l}\text { INDIERCT } \\
\text { BILIRUBIN } \\
\text { (micromol/L) }\end{array}$ & Remarks \\
\hline 13 May & 25 & 36 & & & 22.37 & 3.4 & & Before the treatment \\
\hline $\begin{array}{c}19-28 \\
\text { May }\end{array}$ & & & & & & & & $\begin{array}{l}\text { Methylprednisolone } \\
\text { Bolus with high dose }\end{array}$ \\
\hline 29 May & 23 & 15 & & & 12.10 & & & After the treatment \\
\hline 21 July & 1032 & 2076 & & 178 & 475 & & & $\begin{array}{l}\text { Methylprednisolone } \\
\text { with small dose }\end{array}$ \\
\hline 23 July & 1047 & 1774 & 186 & 175 & & & & \\
\hline 30 July & 387 & 489 & & & 427 & 310.7 & 116.5 & $\begin{array}{c}\text { Spironolactone, } \\
\text { Menadione, } \\
\text { ursodeoxycholic acid }\end{array}$ \\
\hline 07 August & 373 & 483 & 102 & & 370 & 278 & 92 & ursodeoxycholic acid \\
\hline 14 August & 189 & 244 & 56 & & 191.7 & 144,3 & 47.4 & ursodeoxycholic acid \\
\hline $\begin{array}{c}11 \\
\text { September }\end{array}$ & 29 & 50 & 30 & & 56 & 39,6 & 16.3 & \\
\hline $\begin{array}{c}18 \\
\text { December }\end{array}$ & 13 & 28 & 25 & & 13 & 5.4 & 8 & \\
\hline
\end{tabular}


Table 2. Additional para-clinical data.

\begin{tabular}{|c|c|c|c|c|c|}
\hline Complete Blood Count & & Liver Function Tests & & Autoimmune Markers & \\
\hline Hematocrit (Hct)\% & 38.4 & Albumin (g/dl) & 36 & Erythrocyte sedimentation rate (mm/h) & 9 \\
\hline Hemoglobin (Hgb) g/dl & 13.6 & Total protein (g/dl) & 55 & Anti-nuclear antibody( titer) & $<1: 160$ \\
\hline Red Blood Cell (RBC) million/ml & 4.82 & $\begin{array}{l}\text { Prothrombin time } \\
\text { (second)\% }\end{array}$ & 101 & $\begin{array}{l}\text { Anti-smooth muscle antibody (SMA) IgG + A + } \\
\text { M ( titer) }\end{array}$ & $<1: 140$ \\
\hline $\begin{array}{l}\text { Mean corpuscular volume (MCV) } \\
\text { fl }\end{array}$ & 79.7 & INR & 0.95 & $\begin{array}{l}\text { Anti-mitochondrial antibody (AMA) IgG + A + } \\
\text { M (titer) }\end{array}$ & $<1: 140$ \\
\hline $\begin{array}{l}\text { Red cell Distribution Width } \\
\text { (RDW)\% }\end{array}$ & 15.8 & Viral Markers & & $\begin{array}{l}\text { Anti-liver-kidney microsome antibodies IgG }+\mathrm{A} \\
+\mathrm{M} \text { (titer) }\end{array}$ & $<1: 140$ \\
\hline $\begin{array}{l}\text { Mean corpuscular hemoglobin } \\
\text { (MCH) pg }\end{array}$ & 28.2 & $\mathrm{HCV}-\mathrm{Ab}$ & Negative & $\begin{array}{l}\text { anti-gastric parietal cell antibodies IgG }+\mathrm{A}+\mathrm{M} \\
\text { (titer) }\end{array}$ & $<1: 640$ \\
\hline $\begin{array}{l}\text { Mean corpuscular hemoglobin } \\
\text { concentration (MCHC) g/dl }\end{array}$ & 35.4 & HBsAg & Negative & Antibody cardiolipin IgG + A + M () & 0.98 \\
\hline Platelets & 173 & HAV-Ab IgM & Negative & Protein electrophoresis & \\
\hline White Blood Cells (WBCs) & 4.93 & HIV & Negative & Alpha 1 globulin g/l & 2.5 \\
\hline Neutrophils\% & 60.3 & Biochemistry & & Alpha 2 globulin g/l & 3.9 \\
\hline Lymphocytes \% & 24.7 & $\begin{array}{l}\text { Alfa-feto protein } \\
\text { (U/ml) }\end{array}$ & 14.81 & Beta globulin g/l & 6.1 \\
\hline Monocytes\% & 12.8 & Glucose mmol/l & 4.3 & Gamma globulin g/l & 6.8 \\
\hline Eosinophils\% & 1.4 & $\begin{array}{l}\text { Creatinine } \\
\text { micromole/l }\end{array}$ & 63.0 & & \\
\hline \multirow[t]{4}{*}{ Basophils\% } & 0.8 & Urea mmol/l & 4.03 & & \\
\hline & & Cholesterol mmol/l & 6.5 & & \\
\hline & & Iron micromol/l & 37.90 & & \\
\hline & & Calcium mmol/l & 2.35 & & \\
\hline
\end{tabular}

Table 3. Summary of methylprednisolone-induced hepatitis: review of four cases.

\begin{tabular}{|c|c|c|c|c|c|c|c|c|c|}
\hline $\begin{array}{l}\text { Author/ } \\
\text { Reference }\end{array}$ & Age/Gender & Symptoms & $\begin{array}{l}\text { Type of } \\
\text { Steroid }\end{array}$ & $\begin{array}{l}\text { Dose and } \\
\text { duration of } \\
\text { treatment }\end{array}$ & $\begin{array}{l}\text { ALT/AST(U/L) } \\
\text { ALP/GGT(U/L) }\end{array}$ & Diagnosis & Histology & $\begin{array}{l}\text { Concomitant } \\
\text { treatment }\end{array}$ & Follow Up \\
\hline $\begin{array}{l}\text { Yana } \\
\text { Davidov et } \\
\text { al. [10] }\end{array}$ & $\begin{array}{l}23 \\
F\end{array}$ & $\begin{array}{l}\text { jaundice, } \\
\text { malaise and } \\
\text { abdominal pain }\end{array}$ & MP & $\begin{array}{l}1.0 \mathrm{~g} / \mathrm{d} \\
\text { 3days }\end{array}$ & 1515/2011/148/121 & MS & $\begin{array}{l}\text { Hepatocytes } \\
\text { dropout in the } \\
\text { central areas, } \\
\text { accompanied by } \\
\text { congestion and } \\
\text { chronic } \\
\text { inflammation }\end{array}$ & No & $\begin{array}{l}\text { Recovery } \\
\text { after } 3 \\
\text { months }\end{array}$ \\
\hline $\begin{array}{l}\text { Firdevs } \\
\text { Topal et al. } \\
\text { [5] }\end{array}$ & $\begin{array}{l}47 \\
F\end{array}$ & $\begin{array}{l}\text { Weakness, } \\
\text { nausea, } \\
\text { anorexia, } \\
\text { pruritus, } \\
\text { jaundice }\end{array}$ & MP & $\begin{array}{l}0.224 \mathrm{~g} \\
\text { (po)/ } \\
7 \text { days }\end{array}$ & $\begin{array}{l}2478 / 1600 \\
138 / 242\end{array}$ & CNS vasculitis & Not done & Topiramate & $\begin{array}{l}\text { Recovery } \\
\text { after } \\
45 \text { days }\end{array}$ \\
\hline $\begin{array}{l}\text { Rivero et } \\
\text { al. [3] }\end{array}$ & $\begin{array}{l}57 \\
F\end{array}$ & Asymptomatic & MP & $\begin{array}{l}3 \mathrm{~g} \\
\text { (iv)/3 days }\end{array}$ & $\begin{array}{l}1223 / 543 \\
113 / 71\end{array}$ & MS & $\begin{array}{l}\text { Acute hepatitis } \\
\text { with } \\
\text { bridging necrosis }\end{array}$ & NO & $\begin{array}{l}\text { Recovery } \\
\text { after } \\
3 \text { months }\end{array}$ \\
\hline $\begin{array}{l}\text { Melamud } \\
\text { B et al. } \\
{[11]}\end{array}$ & $\begin{array}{l}52 \\
M\end{array}$ & $\begin{array}{l}\text { Weakness, } \\
\text { arthralgia, } \\
\text { jaundice }\end{array}$ & MP & $\begin{array}{l}2.25 \mathrm{~g} \\
\text { (iv) } / 5 \\
\text { weeks }\end{array}$ & $\begin{array}{l}465 / 283 \\
80 / 185\end{array}$ & $\begin{array}{l}\text { Graves' } \\
\text { ophthalmopathy }\end{array}$ & Not done & $\begin{array}{l}\text { Levothyroxin } \\
\text { Atorvastatin }\end{array}$ & $\begin{array}{l}\text { Recovery } \\
\text { after } \\
\text { Seven } \\
\text { months }\end{array}$ \\
\hline $\begin{array}{l}\text { Present } \\
\text { Case }\end{array}$ & $\begin{array}{l}51 \\
F\end{array}$ & $\begin{array}{l}\text { Weakness, } \\
\text { anorexia, } \\
\text { weight loss and } \\
\text { Jaundice }\end{array}$ & MP & $\begin{array}{l}500 \text { mg in } \\
\text { No.10 for } \\
10 \text { days }\end{array}$ & 1032/2076/178/186 & MS & Not done & No & $\begin{array}{l}\text { Recovery } \\
\text { after Six } \\
\text { months }\end{array}$ \\
\hline
\end{tabular}

F: Female, M: Male, MP: Methylprednisolone, MS: Multiple Sclerosis.

with multiple sclerosis we performed a literature review search for PubMed articles for the years of 2000-2016 using keywords: drug induced liver injury, hepatotoxicity drugs, high-dose methylprednisolone, acute hepatitis, 
toxic hepatitis, steroids, liver toxicity, demyelinating disease and MeSH terms: Drug-Induced Liver Injury, multiple sclerosis, methylprednisolone and hepatitis. We identified more than ten cases of methylprednisolone induced liver injury and we compare four cases that has been reported in our present case (Table 3) and most of that cases were women including in our case. This can be explained by the higher incidence of multiple sclerosis among women ((3.6 cases per 100,000 person-years) compared with men (2.0 per 100,000 person-years). In addition, the female-to-male multiple sclerosis ratio has increased over the last years [9]. Although the steroids have rarely associated with liver injury; moreover, they are the treatment of choice for severe hepatitis and to date there are cases that methylprednisolone induced liver injury have previously been reported. In our case, it is similar for those with regard to mixed hepatocellular liver injury and chlostestic injury. The general awareness of this liver injury of high-dose steroids is very low. Steroids induced liver injury may be more common than usually supposed. We therefore conclude that liver injury related to methylprednisolone should be considered in patients who develop liver injury or elevated liver enzymes while receiving this steroid and making follow-up monitoring of liver tests after being given methylprednisolone.

\section{Conclusion}

In conclusion, although methylprednisolone was widely used by neurologists, endocrinologists and rheumatologists to treat many autoimmune diseases and in our case emphasized the possible effect of high dose of methylprednisolone in the induction of transient hepatopathy. In the literature, there are sporadic observations of severe drug-induced hepatitis, more than half of them are the result of corticosteroid treatment of multiple sclerosis. It is unknown whether this association is random if there are common genetic predictors of multiple sclerosis and idiosyncrasy to corticosteroids. And the most important question is: how to treat multiple sclerosis in patients with hepatotoxicity them?

\section{References}

[1] Longo, D. and Fauci, A. (2013) Harrison of Gastroenterology and Hepatology. 2nd Edition, McGraw-Hill Education, New York, 385.

[2] Kleiner, D.E., Chalasani, N.P., Lee, W.M., Fontana, R.J., Bonkovsky, H.L., Watkins, P.B., Hayashi, P.H., et al. (2014) Hepatic Histological Findings in Suspected Drug-Induced Liver Injury: Systematic Evaluation and Clinical Associations. Hepatology, 59, 661-670. http://dx.doi.org/10.1002/hep.26709

[3] Fernandez, M.R., Riesco, J.M., Moreira, V.F., et al. (2008) Recurrent Acute Liver Toxicity from Intravenous Methylprednisolone. Revista Espanola de Enfermedades Digestivas, 100, 720-723. http://dx.doi.org/10.4321/S1130-01082008001100010

[4] Gutkowski, K., Chwist, A. and Hartleb, M. (2011) Liver Injury Induced by High-Dose Methylprednisolone Therapy: A Case Report and Brief Review of the Literature. Hepatitis Monthly, 11, 656-661. http://dx.doi.org/10.5812/kowsar.1735143X.641

[5] Topal, F., Ozaslan, E., Akbulut, S., Kucukazman, M., Yuksel, O. and Altiparmak, E. (2006) Methylprednisolone-Induced Toxic Hepatitis. Annals of Pharmacotherapy, 40, 1868-1871. http://dx.doi.org/10.1345/aph.1H171

[6] Kaplowitz, N. (2005) Idiosyncratic Drug Hepatotoxicity. Nature Reviews Drug Discovery, 4, 489-499. http://dx.doi.org/10.1038/nrd1750

[7] Weissel, M. and Hauff, W. (2000) Fatal Liver Failure after High-Dose Glucocorticoid Pulse Therapy in a Patient with Severe Thyroid Eye Disease. Thyroid, 10, 521.

[8] Marinó, M., Morabito, E., Brunetto, M.R., Bartalena, L., Pinchera, A. and Marocci, C. (2004) Acute and Severe Liver Damage Associated with Intravenous Glucocorticoid Pulse Therapy in Patients with Graves' Ophthalmopathy. Thyroid, 14, 403-406. http://dx.doi.org/10.1089/105072504774193276

[9] Alonso, A. and Hernan, M.A. (2008) Temporal Trends in the Incidence of Multiple Sclerosis: A Systematic Review. Neurology, 71, 129-135. http://dx.doi.org/10.1212/01.wnl.0000316802.35974.34

[10] Davidov, Y., Har-Noy, O., Pappo, O., Achiron, A., Dolev, M. and Ben-Ari, Z. (2016) Methylprednisolone Induced Liver Injury: Case Report and Literature Review. Journal of Digestive Diseases, 17, 55-62.

[11] Melamud, B., Lurie, Y., Goldin, E., Levi, I. and Esayag, Y. (2014) Methylprednisolone-Induced Liver Injury: A Diagnostic Challenge. Israel Medical Association Journal, 16, 180-181. 